\title{
Establishment of Silvopasture in Existing Pastures ${ }^{1}$
}

Jarek Nowak, Alan Long and Ann Blount ${ }^{2}$

Private forest landowners and cattle ranchers who combine timber, forage, and livestock into one production system increase the benefits they might receive from their land compared to management for just one of these commodities. This intentionally integrated and intensively managed system, known as silvopasture, can diversify revenue, enhance environmental benefits, and boost aesthetics of agricultural or forestry operations. Diversified cash flow is becoming especially important as landowners face unfavorable product prices when they rely on just a single commodity. Silvopasture is different from rangeland or woodlot grazing in that it employs improved forage. Rangeland grazing relies on native forages, whereas there may be no real forage except for opportunistic browse in woodlot grazing. Silvopasture has been practiced in the Southeast as "tree-pasture" or "pine-pasture" since the early 1950s.

Silvopasture establishment requires a number of different management steps depending on previous land use. Planting trees in an existing improved pasture is the easiest way to start the system. Another possible scenario is to thin existing timber stands and plant or seed forage species among the remaining trees. This publication discusses establishment of silvopastoral systems in existing improved pastures.
Information presented here is applicable to north Florida and other Southeastern states where tree and forage growing conditions are similar.

\section{Converting Pastures to Silvopastures}

Silvopastures are usually established by planting trees in existing pastures. This eliminates costs of forage establishment, shrub and brush control, or removal of timber harvest residues. Well established and managed bahiagrass, bermudagrass, or other similar pastures are most suitable. Planting density varies from 100 to 450 trees per acre depending on tree species, product objectives, and anticipated level of management intensity. If fewer trees are planted, thinning of pulpwood size trees may not be necessary. However, when grown at wider spacings, most species will require pruning for quality timber production. Standard tree planting methods and equipment can be used, as described below.

\section{Site Preparation}

Site preparation before tree planting improves seedling survival and early growth by reducing competition from grass and other vegetation for water, nutrients, and light. Proper site preparation can

1. This document is FOR107, one of a series of the School of Forest Resources and Conservation, University of Florida, Florida Cooperative Extension Service, Institute of Food and Agricultural Sciences. Publication date: June 5, 2003. Reviewed: July 2004. Please visit the EDIS Web site at http://edis.ifas.ufl.edu.

2. Jarek Nowak, Assistant Professor of Forestry, University of Florida, NFREC-Quincy, FL; Alan Long, Associate Professor of Forestry, University of Florida, SFRC, Gainesville, FL; Ann Blount, Assistant Professor, Department of Agronomy, University of Florida, NFREC-Marianna, FL

The Institute of Food and Agricultural Sciences (IFAS) is an Equal Employment Opportunity - Affirmative Action Employer authorized to provide research, educational information and other services only to individuals and institutions that function without regard to race, creed, color, religion, age, disability, sex, sexual orientation, marital status, national origin, political opinions or affiliations. For information on obtaining other extension publications, contact your county Cooperative Extension Service office. Florida Cooperative Extension Service / Institute of Food and Agricultural Sciences / University of Florida / Larry R. Arrington, Interim Dean 
be achieved by chemical, mechanical, or prescribed fire treatments applied alone or in combination. The method of choice depends on site conditions, vegetation to be controlled, treatment costs, and other considerations, such as herbicide acceptability or smoke from prescribed fires.

Chemical site preparation consists of herbicide applications before trees are planted. Herbicides are most often sprayed in bands along planting rows, or around planting spots. Pre-planting treatments allow for higher application rates, and therefore greater possibility of success in controlling competition. Chemical site preparation offers the longest lasting effects for competition control where it is needed most, within rows of planted trees. Reduction of competition is a key to rapid seedling establishment. Broadcast herbicide application is usually not necessary, unless current pasture is to be replaced with more suitable forage species. Under most circumstances, banded application, or even spot applications, should be sufficient to control vegetation competing with trees at a lower cost than broadcast applications. Some common herbicide treatments include Arsenal, or Velpar with Oust in the spring, or tank mixes of Accord with Arsenal in the fall. In bermudagrass pastures, Arsenal or Accord must be used. You should read the herbicide label prior to application for recommended rates, mixing instructions, and plant species controlled.

Scalping is a very effective mechanical site preparation technique on pastures. By exposing mineral soil, scalping prepares a furrow for tree planting machines and generally reduces weed competition during the next growing season. Sod and grass are stripped along intended tree rows by a tractor-pulled scalping plow. Some sites may also require subsoiling before planting. A metal shank is pulled behind the tractor at soil depths up to 24 inches. Subsoiling breaks existing "plow pans" or other "hard pans". Furrows allow for easier tree root penetration leading to better tree survival and establishment after planting. Scalping and subsoiling, or scalping and tree planting are sometimes combined into one operation with the right implements attached to a tractor. Scalping alone may not help with bermuda grass, which can quickly spread back across the opening.
Disked strips can also be used to break up sod and prepare planting rows. As with scalping, untreated areas are left between planted rows to protect soil and provide forage. Disking and scalping should always follow contours on slopes.

Prescribed fire recycles nutrients and temporarily reduces competition from herbaceous and other vegetation. It has an added benefit of increasing forage palatability. It should be applied shortly before tree planting. It is usually the cheapest site preparation option, but most pasture grasses resprout quickly after a fire.

Combination of methods, such as broadcast herbicide application followed by prescribed fire, or banded herbicides along scalped rows, may be necessary if shrubs, undesirable perennials, and vines need to be controlled. Prescribed fire (with or without prior herbicide application) may be followed by a mechanical site preparation treatment.

\section{Tree Species Selection}

Both coniferous and broadleaved species could be considered for establishment of silvopasture and other agroforestry practices. Among southern pine species, slash pine is the most suitable for silvopasture, because of light crowns and good self-pruning abilities. This species grows best on moderate to poorly drained sandy soils. Loblolly pine has the greatest growth potential among the southern pines, and is a good match for well-drained upland and clay soils. However, loblolly pine tends to have more and thicker branches than slash pine, which makes it less suitable for silvopastures, unless the lower branches can be pruned as the trees mature. Longleaf pine can be planted both on upland and wetter, flatwood sites. It has good crown characteristics and the greatest potential for high value timber products among the southern pine species; however, it is also the hardest species to establish in grass. Pecans are the most commonly grown broadleaved trees suitable for silvopasture. Detailed criteria for tree species selection are provided in Circular 1430 (Nowak et al., 2002). In addition, online decision support systems available at http://cstaf.ifas.ufl.edu can help in matching tree and shrub species suitable for silvopasture and other 
agroforestry practices in the Southeast, depending on local soil and climatic conditions.

\section{Seedling Types}

Genetically improved tree seedlings are preferred for establishment of silvopastures. It is especially important to use fusiform rust resistant seedlings if slash or loblolly pines are planted. Large caliper seedlings grown at low density in a nursery have much more desirable root characteristics than smaller diameter seedlings grown in crowded nursery beds. Well-developed, fibrous root systems speed up successful seedling establishment. Bare root seedlings are cheaper than containerized trees, but they need to be planted during winter. Containerized seedlings work well, especially for longleaf pine, and they can be planted either during the winter or after summer rains begin.

\section{Tree Spacing at Planting}

Silvopasture requires tree spacing that allows for sufficient timber and forage yields. A $4 \times 8 \mathrm{ft}$ tree spacing with $40 \mathrm{ft}$ forage alleys between pairs of tree rows was found to best satisfy these requirements in Georgia and Florida experiments (Lewis et al., 1985). This double-row $4 \times 8 \times 40 \mathrm{ft}$ tree spacing (Figure 1) yielded more wood and forage than single-row $8 \times 12$ $\mathrm{ft}$ control treatments in the same experiments (Table 1). Ever since the mid-1980s, this tree-planting pattern has continued to be popular for establishment of silvopastures in Florida (Figure 2).

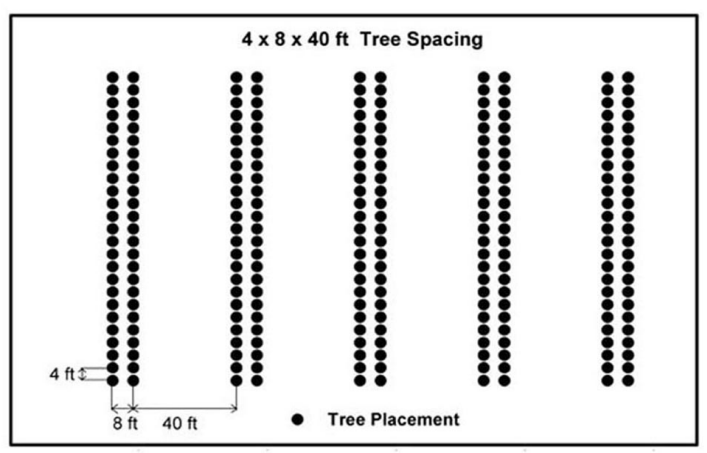

Figure 1. Double-row $4 \times 8 \mathrm{ft}$ tree spacing with $40 \mathrm{ft}$ wide alleys between pairs of tree rows (also known as $4 \times 8 \times 40 \mathrm{ft}$ spacing) was found to satisfy both timber and forage growth requirements (Lewis et al., 1985).

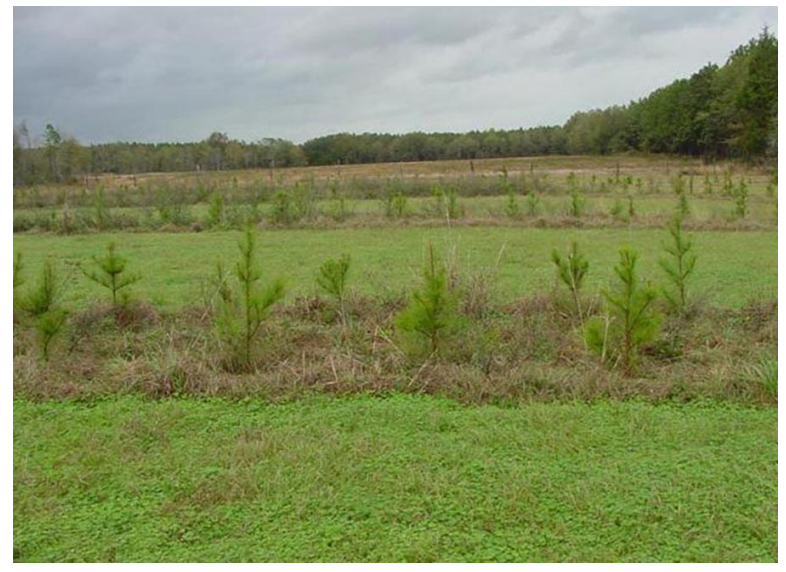

Figure 2. Loblolly pine planted in $4 \times 8 \times 40 \mathrm{ft}$ spacing in bahiagrass - crimson clover pasture after one growing season in the field (George Owens farm near Chipley, FL, December 2001).

Other tree arrangements in silvopastures are also possible. Trees can be planted in single wide-spaced rows, sets of multiple rows with wide alleys between the sets, or in clusters. In any tree arrangement, open areas between trees allow for forage production. Planting trees in rows facilitates access for future forage and silvicultural operations (Sharrow, 1999). Therefore, planting trees in rows is preferred over random tree placement or planting tree clusters. Generally, wide spacing between single rows, or wide alleys between sets of multiple rows supports higher levels of forage production than closely spaced rows. However, too much open pasture space also means less wood production on a per acre basis. The trade-offs between timber and forage production are well illustrated by comparing yields of both commodities in $4 \times 8 \times 40$ and $2 \times 8 \times 88 \mathrm{ft}$ spacings. The $4 \times 8 \times 40 \mathrm{ft}$ tree pattern produced twice as much wood as the $2 \times 8 \times 88$ tree spacing, whereas the opposite was true for forage production (Table 1).

\section{Tree Planting}

Trees are best planted with a mechanical planter, but hand planting is also possible, especially on small or irregular tracts of land. Machine planting produces straight rows and uniform spacings, which is important in silvopastoral systems. General guidelines for planting trees in silvopastures are the same as for establishing tree plantations. Plant trees on the contour wherever pastures are on slopes. Staying in scalps and furrows while planting trees should not pose any difficulties. However, more 
Table 1. Average tree and forage responses of slash pine at age 13 . Trees were planted in single $(8 \times 12,4 \times 24,2 \times 48 \mathrm{ft})$ and double-row $(6 \times 8 \times 24,4 \times 8 \times 40,2 \times 88 \times 88 \mathrm{ft})$ configurations at 454 trees per acre (adapted from Tanner and Lewis, 1984).

\begin{tabular}{||l|l|l|l|l|l|l||}
\hline \hline & $8 \times 12$ & $4 \times 24$ & $2 \times 48$ & $6 \times 8 \times 24$ & $4 \times 8 \times 40$ & $2 \times 8 \times 88$ \\
& & & & & & \\
\hline Tree Survival (\%) & 61 & 68 & 68 & 67 & 67 & 74 \\
\hline Tree Height (ft) & 35 & 35 & 36 & 32 & 36 & 34 \\
\hline Tree Diameter (in) & 5.7 & 5.2 & 5.1 & 5.0 & 5.5 & 4.3 \\
\hline Stand Basal Area (ft'/ac) & 50 & 49 & 52 & 40 & 59 & 33 \\
\hline Wood Volume (ft /ac) & 903 & 866 & 973 & 658 & 1,086 & 580 \\
\hline Total Forage Yield (Ib/ac) & 1,138 & 542 & 1,069 & 1,347 & 1,264 & 2,573 \\
\hline \hline
\end{tabular}

effort may be needed to plant trees inside herbicided bands if the treated vegetation has not yet discolored. At planting, care needs to be exercised not to bend roots upwards, which causes "j-rooting", and may lead to low seedling survival. Soil should be firmly packed and cover each seedling root collar (the juncture between tap root and the shoot). When planting longleaf pine seedlings, pack the soil below the terminal bud. If planting bare root stock, keep seedlings and roots moist and in the shade from the time they are lifted from nursery beds until planted in the field.

\section{Tree Survival and Establishment}

Post-planting treatments are often necessary for best tree survival and establishment results. Grass and weeds often quickly reoccupy scalped or disked rows and they need to be controlled with herbicides during the first and/or second year after planting. Banded or spot herbicide applications along tree rows (up to 4 feet across) are most effective in controlling unwanted vegetation. The following herbicides can be used: (1) Oust, Arsenal or Accord on bahiagrass; (2) Arsenal, Accord, or Fusilade on bermudagrass; (3) Arsenal, Oust, or Oustar, as single herbicide treatments, or tank mixes of Oust with Velpar, Arsenal or Accord for other grasses and herbaceous vegetation. Please consult labels prior to herbicide applications for appropriate rates, mixing instructions and plant species that can be controlled with each herbicide. It is best to protect tree seedlings from direct contact with the herbicides, although some are labeled for "over the top applications." Stressed seedlings are more prone to herbicide-caused damage than healthy and vigorous ones. Tank mixes may be more damaging than any of the herbicides applied alone. For example, applying Velpar or Arsenal with Oust may increase damage to new slash or longleaf pine seedlings.

Mowing between the rows of trees is advised several times a year during the first three growing seasons after tree planting. Mowing helps to further reduce the competition from grasses and increase light available to tree seedlings. If the grass yield is sufficient, mowing can be done as part of haying operations to provide revenue from forage during the years before cattle are allowed to graze on the site. Mowing, hay cutting, or any other operation that requires driving equipment between the rows of trees 
needs to avoid hitting the seedlings or scuffing off the bark.

Successful establishment of trees in the existing pastures concludes the first phase of pasture to silvopasture conversion. Livestock can be introduced to the system when trees reach sufficient heights to prevent damage to terminal buds from browsing or nubbing. Longleaf pine may remain stemless for several years, whereas loblolly pine and slash pine resume height growth in the spring after planting. Therefore typically, grazing under planted loblolly and slash pines is possible sooner than under longleaf pine canopies. After livestock are integrated into the system, continued intensive management of all three components (forage, livestock, and trees) is needed to realize potential economic and environmental benefits offered by silvopasture.

Some of the possible livestock choices and criteria to help guide livestock selection are described in Integrated Timber, Forage and Livestock Production - Benefits of Silvopasture, Florida Cooperative Extension Service Circular 1430 (Nowak et al., 2002). Cattle management in pine bahiagrass systems is discussed in Circular 1154 (Tyree and Kunkle, 1995), and forage management on timberlands in publication SS-FOR-20 (Demers and Clausen, 2002). An electronic version of these and other University of Florida, IFAS extension publications relevant to tree, forage and livestock management can be found at: http://edis.ifas.ufl.edu/.

\section{In Summary}

Silvopastures are intentional, integrated, and intensively managed systems designed to optimize timber, forage, and livestock production from the same acreage at the same time. One way of establishing a silvopasture is to plant trees in an improved pasture. Standard plantation forestry site preparation methods are used in silvopasture establishment. These include site preparation with herbicides, scalping plows, or prescribed fire. All three commonly planted southern pines are suitable, however slash pine is easier to establish than longleaf pine, and both have all the desirable crown and wood characteristics. Loblolly pine, although also suitable, tends to have more and thicker branches than the other two species, which is less desirable for both wood and under-canopy forage production. Bare root or containerized seedlings can be planted, with the latter extending the planting season beyond the winter months. The most popular tree spacing for silvopasture establishment is a double-row configuration $4 \times 8 \times 40 \mathrm{ft}$. This tree planting pattern produced more wood and forage than the typical $8 \times 12$ $\mathrm{ft}$ plantation spacing in Florida and Georgia experiments. Twice as much wood was produced in the $4 \times 8 x 40 \mathrm{ft}$ than in $2 \times 8 x 88 \mathrm{ft}$ tree spacing. The reverse was true for forage production.

\section{Literature Cited}

Demers, C. and R. Clausen. 2002. Managing Cattle on Timberlands: Forage Management. Florida Cooperative Extension Service, IFAS, University of Florida. SS-FOR-20. 7p.

Lewis, C.E., G.W. Tanner, and W.S. Terry. 1985. Double vs. Single-Row Pine Plantations for Wood and Forage Production. Southern Journal of Applied Forestry, 9(1): 55-61.

Nowak, J., A. Blount, and S. Workman. 2002. Integrated Timber, Forage, and Livestock Production - Benefits of Silvopasture. Florida Cooperative Extension Service, IFAS, University of Florida. Circular 1430. $7 \mathrm{p}$.

Sharrow, S.H. 1999. Silvopastoralism: Competition and Facilitation Between Trees, Livestock and Improved Grass-Clover Pastures on Temperate Rainfed Lands. In: Agroforestry in Sustainable Agricultural Systems. L.E. Buck, J.P. Lassoie and E.C.M. Fernandes Eds. CRC Press LLC. Boca Raton, Florida. 416p.

Tanner, G.W. and C.E. Lewis, 1984. Alternative Tree Spacings for Wood and Forage Production in Florida. Florida Cooperative Extension Service, IFAS, Forest Resources and Conservation Fact Sheet FRC-36. University of Florida, Gainesville. 2p.

Tyree, A. B. and W.E. Kunkle. 1995. Managing Pine Trees and Bahiagrass for Timber and Cattle Production. Florida Cooperative Extension Service, IFAS, University of Florida. Circular 1154. 10p. 


\section{Acknowledgements}

Authors are grateful to Mr. George Owens for providing opportunities to photograph and discuss the silvopastoral operations on his farm near Chipley, Florida. This is one of the series of extension publications on agroforestry by the Center for Subtropical Agroforestry (CSTAF), Web site: http://cstaf.ifas.ufl.edu, at the School of Forest Resources and Conservation, IFAS, University of Florida, Gainesville, Florida. 